\title{
29. CIRCUM-CARIBBEAN EXPLOSIVE VOLCANIC ACTIVITY: EVIDENCE FROM LEG 15 SEDIMENTS
}

\author{
Thomas W. Donnelly, Department of Geology, State University of New York, Binghamton, New York
}

\section{INTRODUCTION}

The Cretaceous and Tertiary history of the entire circum-Caribbean area is one of widespread volcanic activity. However, one of the most important problems in tectonic synthesis - the chronology of vulcanism - is relatively difficult to study on land in the immediate vicinity of the volcanic centers themselves. Volcanic deposits close to the source tend either to be terrestrial, hence unfossiliferous, or very sparsely fossiliferous shallow marine. Units are thick and monotonous, and correlations are difficult. In an area of active recent vulcanism, such as the Lesser Antilles, the older deposits are buried, and geological tradition commonly holds that vulcanism in such places started with the age of the oldest rocks which are exposed. Probably one of the potentially most powerful means of determining the record of explosive volcanic activity, therefore, is to examine deep-sea sediments adjacent to the islands. Leg 15 (Figures 1, 2, and 3) produced cores which are rich in volcanic materials, and a study of these materials provides valuable inferences about volcanic activity.

\section{VOLCANIC MINERALOGY}

Feldspar: Plagioclase is the most widely distributed calc-alkaline volcanic mineral. It is remarkably resistant to etching and solution, but it does become rounded in pelagic clays (Plate 1, Figure 2). In zeolitic clays it is very fresh, with sharply defined crystal faces, including very minor prismatic, dome, and pyramidal faces (Plate 1, Figure 3). The plagioclase of pumiceous siliceous sediments, such as the late Eocene and Oligocene sediments of Site 149, is commonly coated with glass remnants which give the mineral in reflected light an altered appearance although it is quite fresh (Plate 1, Figure 1). Much, if not most, of the plagioclase seen is calcic (high refractive index) with simple twinning and oscillatory zoning (Plate 5, Figure 5). Marginal alteration of grains is not apparent. Fluid inclusions, many with a second phase, and glass inclusions are abundant. Inclusions of apatite crystals have been found in nine samples from Site 146/149, 150, and 151. One Pliocene, four Miocene, one late Oligocene, one mid Eocene, and two late Cretaceous. Plagioclase grains are generally less than $0.5 \mathrm{~mm}$ long, but some are larger than 2 $\mathrm{mm}$. The larger grains are almost certainly pumice rafted.

Alkali Feldspar: Alkali feldspar is of more restricted occurrence. Recognition of this mineral as volcanic, rather than authigenic, has been based on the presence of fractured grains, lack of inclusions, low optic angle, and generally fresh appearance. By contrast, authigenic $\mathrm{K}$-feldspar is euhedral, is crowded with inclusions, and has a high optic angle.
Quartz: Quartz is a relatively scarce mineral occurring generally with biotite, apatite, and, to a lesser extent, with alkali feldspar. Most quartz is bipyramidal (Plate 2, Figure 3 ), with many grains showing the characteristic "wormeaten" magmatic resorption of calc-alkaline volcanic rocks. Quartz crystals are commonly between 0.5 and $1 \mathrm{~mm}$ in diameter.

Two occurrences (Sample 146-16-4,81, Maestrichtian; Samples 152-10-1,148 and 152-10,CC, early Paleocene) of rounded, subspherical quartz were noted (Plate 2, Figure 4, Plate 4, Figure 3 and 4). Although this type of magmatic resorption is rare, there are occurrences in the late Tertiary of the Lesser Antilles (John Tomblin, personal communication). The rounded quartz grains of the three samples at the two localities are remarkably uniform in size; those at Site 146 average $0.09 \mathrm{~mm}$ parallel to $c$ axis and $0.07 \mathrm{~mm}$ at Site 152. In all cases there was a standard deviation of about $0.02 \mathrm{~mm}$.

Biotite: Biotite is scarce, occurring mainly with quartz and apatite. Fresh flakes are easily recognized, but more altered material can be confused with fish bone debris. Although the latter generally have the apatite fibers lying horizontal, a small percentage have the fibers oriented normal to the plate. This results in the same optically negative, uniaxial figure as biotite. A small percentage of biotite flakes have hexagonal holes which have evidently been occupied by apatite crystals.

Hornblende: Hornblende is second only to plagioclase in frequency of occurrence in the smear slides studied. It is almost invariably a greenish color, pleochroic from olive to clear green. A few occurrences of bright red (oxidized) hornblende were noted in the central Caribbean. This mineral is rather common at Site 154 and less common at Site 148.

Pyroxenes: The most common pyroxene noted is clinopyroxene, probably augite. Pyroxene invariably shows a crystallographically controlled etch pattern (Plate 2, Figure 2; Plate 5, Figures 1 and 2), but is sufficiently resistant to solution to occur commonly in pelagic clays. Orthopyroxene was noted in only three instances in the central Caribbean. Its pleochroism, elongation, and orthorhombic etch pattern (Plate 5, Figure 1) make it easily recognized.

Apatite: Apatite is a surprisingly widespread volcanic mineral, being noted in fifty cores from Leg 15 . It is especially conspicuous in late Cretaceous sediments of Sites 146 and 152 . Apatite is easily recognized; most crystals are euhedral or rounded subhedral (Plate 6) and generally have good prismatic and dome faces. A few basal plates were noted (Plate 6, Figure 3). The larger apatite crystals commonly have two-phase fluid inclusions proving their igneous origin. Inclusions, but not the second phases, are 


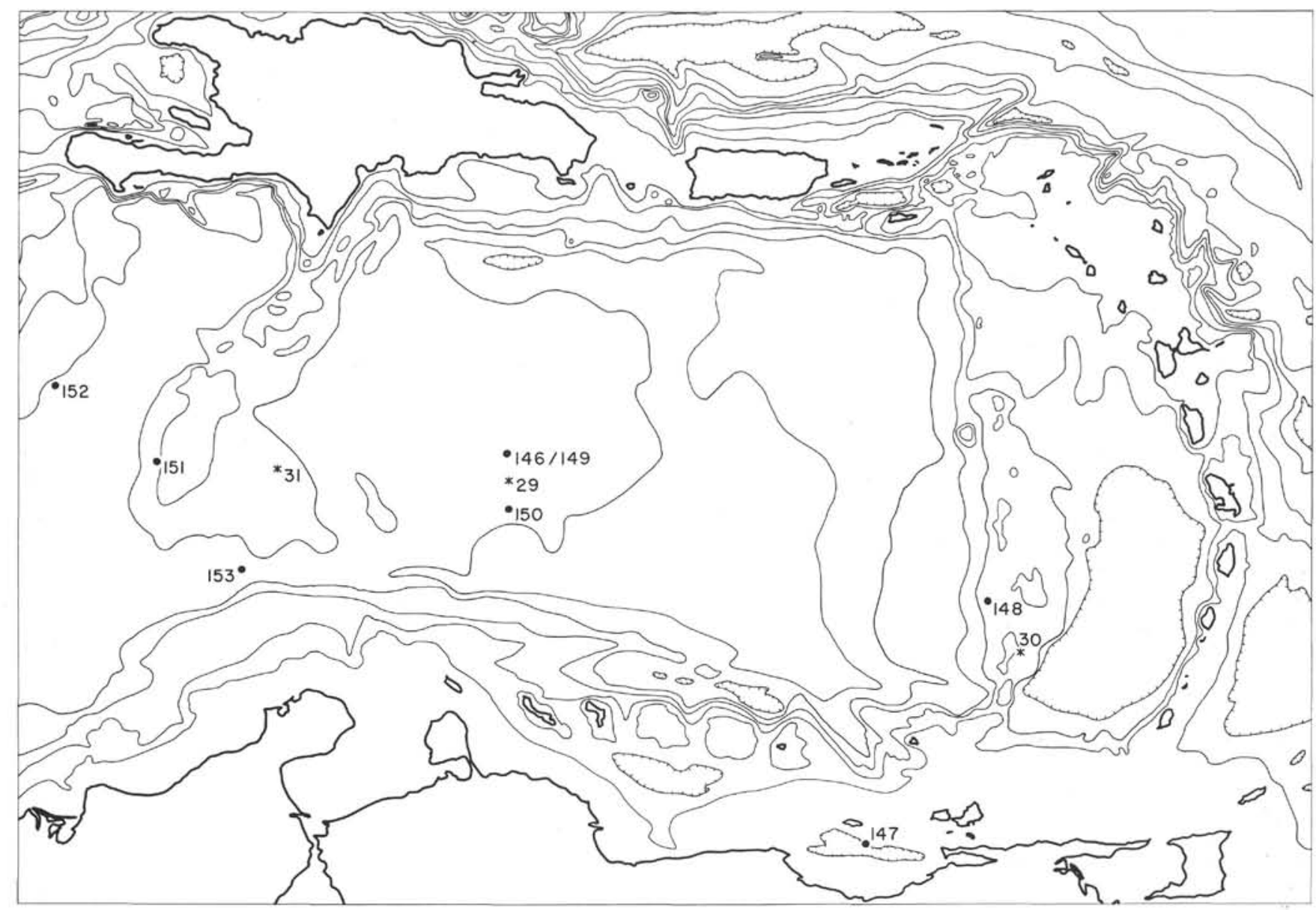

Figure 1. Map of eastern and central Caribbean showing Leg 4 and 15 Sites.

visible in Plate 6, Figures 1 and 2. Also demonstrating their igneous origin is their occurrence with biotite, which commonly shows hexagonal cavities in the flakes. The conclusion is that apatite was largely transported within drifting and slowly settling biotite flakes which subsequently commonly dissolved leaving the included apatite crystals behind. Apatite crystals are commonly 25 to 50 microns long and less commonly as long as 500 microns.

Zircon: Zircon (Plate 5, Figures 3 and 4) is an uncommon associate of quartz, alkali feldspar, biotite, and apatite. Most crystals are prisms with well developed dome and pyramid faces; a few crystals are almost equant. The crystals are commonly around 100 microns long and extremely fresh. In many cases they show reentrants where they had grown around another crystal subsequently removed by solution. Within the central Caribbean it is conspicuous in a few older occurrences (Samples 146-28-2,56, Campanian; 146-29-1,138, late Santonian; 153-4-1,10, Miocene; and 153-15-1,84, Campanian). At Site $154 \mathrm{~A}$, zircon occurs in Cores 3 and 16 of the pelagic sequence, and is found in several instances within the lower turbidites of Sites 154 and 154A. Within the heavy mineral suits of the continental turbidites, zircon is conspicuous (Samples 150-4-1,90 and 31-7-1,131-132). This zircon is easily distinguished from volcanic zircon; it is more or less rounded, pink to brownish (metamict), and has internal dark color zonation.
Volcanic Glass: Volcanic glass occurs locally in the upper part of Site 154 (Core 8 and above) and in the pelagic portion of Site 154A (Core 11 and above). In the lower, turbidite portion of Sites 154 and 154A, it is more widespread. In the central Caribbean, it is widespread in Site 146/149, in the early Miocene and Oligocene of Site 151 , and in the Paleocene of Site 152 (Figure 4). At Site $146 / 149$, and to a lesser extent at Site 151 , the glass is recognizable as pumice lumps. In other instances it occurs either as rather flat, clear, and irregular plates, or as small shards derived from the comminution of tubular pumice (Plate 4, Figures 1 and 2). The glass is generally clear and of moderately low relief. In Sample 152-2-1(139), however, it is distinctly brown and with an index of refraction greater than the mounting medium (Caedex).

The alteration of glass is not often observed. Some occurrences, especially at Site 152 , show a minor development of clay (probably montmorillonite), but generally no alteration can be seen. Recognizable ash beds in the late Cretaceous of Sites 146 and 150, however, have glass "shards" evidently transformed completely to montmorillonite. Zeolitized glass was not found. In only a few smear slides from Site 154 were glass and phillipsite even found together, and in no case could the glass be observed transforming into zeolite. Glass is persistent in calcareous or siliceous sediments, but was not found in pelagic or zeolitic clays. 
$146 / 149 \quad 150 \quad 151 \quad 152 \quad 153$
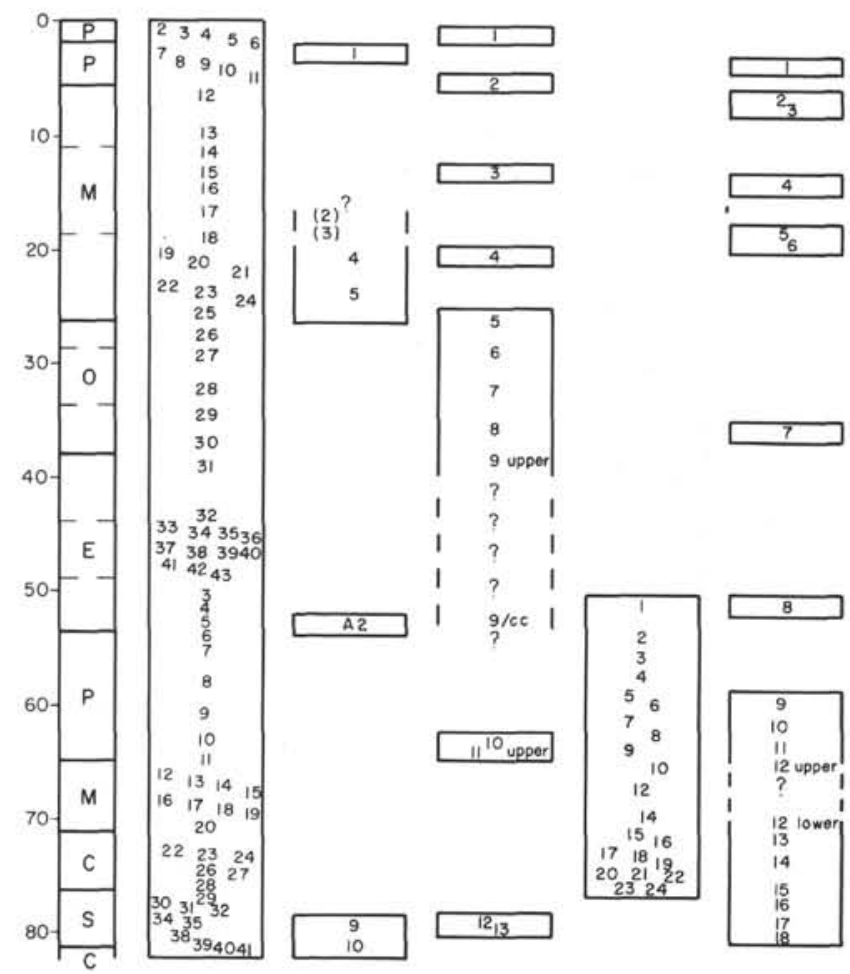

Figure 2. Location of cores referenced in Figures 3-5, 8, 9 for the central Caribbean. Time scale in millions of years and stratigraphic scale on left. $P=$ Pleistocene, $P=$ Pliocene, $M=$ Miocene, $O=$ Oligocene, $E=$ Eocene, $P=$ Paleocene, $M=$ Maestrichtian, $C=$ Campanian, $S=$ Santonian, $C=$ Coniacian.

Zeolites: Zeolites are widespread in the central Caribbean and at Site 154. They are commonly, but perhaps not invariably, associated with recognizable volcanic deposits. They are discussed in another chapter (Donnelly, Mineralogy and chemistry of noncalcareous sediments, this volume).

Other minerals: Magnetite (Plate 2, Figure 1) is widespread and fresh, and commonly occurs as inclusions in plagioclase. An occurrence of garnet is discussed in another chapter.

\section{RECOGNITION OF VULCANISM IN DEEP-SEA CORES}

In only a relatively few instances (at Sites $148,154 \mathrm{~A}$, and in the Oligocene to late Cretaceous of Sites 146 and 150 ) were discrete ash beds or occurrences of pumice noted in the sediment cores (Plate 3, Figures 1 and 2). The disturbance caused by drilling in the less coherent sediments often effectively destroys fine ash laminations. Volcanic ash was detected by high gamma-ray activity in only one instance (Sample 146-20-2, 100, Maestrichtian). Of all the agencies for destruction or dispersal of volcanic detritus, burrowing is probably the most effective. In pelagic clay sequences, however, chemical disintegration of volcanic glass is also very effective, though in calcareous and siliceous sediments this effect may be less serious.
$146 / 149 \quad 150 \quad 151 \quad 152$

153

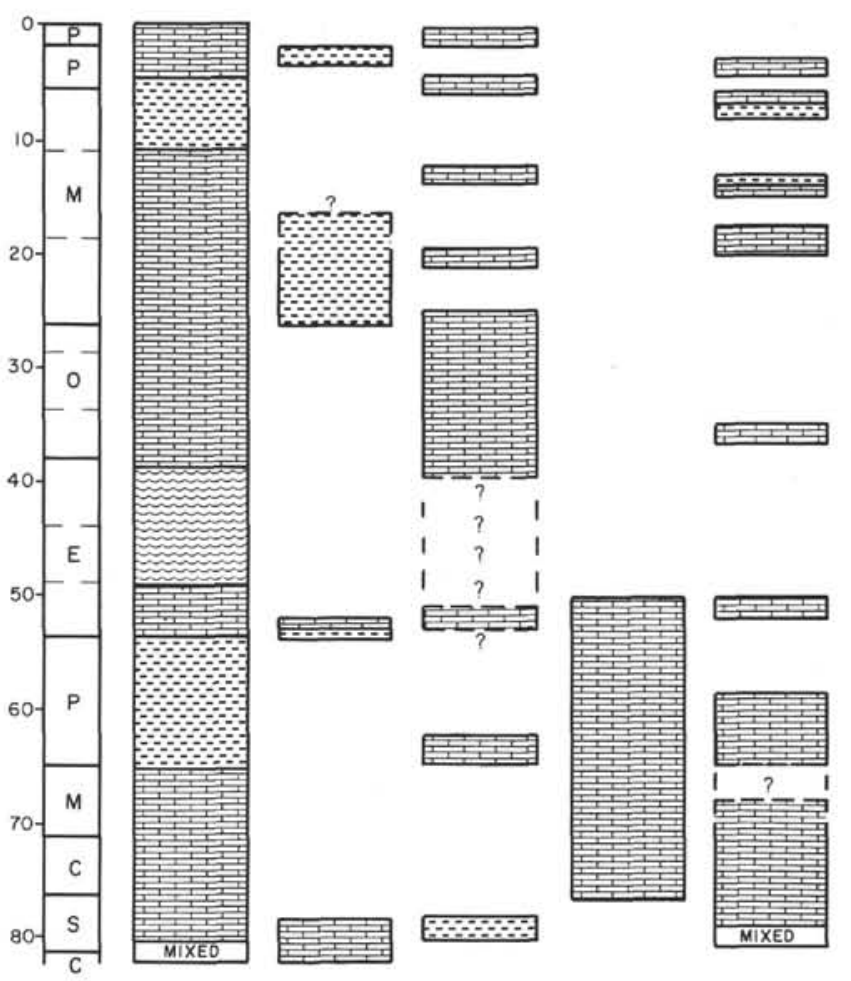

Figure 3. Distribution of three basic lithologic types in the central Caribbean. Lined pattern $=$ clay (including siliceous clay); brick pattern = lime; wavy pattern = siliceous ooze. Plotted against time as explained in caption of Figure 2.

The widespread occurrence of plagioclase and the persistence of this mineral in pelagic clays suggests that its occurrence may be a fair index of explosive, calc-alkaline volcanic activity. Figure 5 shows the percentages of smear slides in which plagioclase was found in the central Caribbean. Plagioclase is especially prominent in sediments from the mid-Eocene through the Oligocene which corresponds to the distribution of pumice; it is less prominent in sediments from the early and mid-Miocene; and is absent in late Miocene sediments (a pelagic clay sequence). It is present again in sediments from the Pliocene and Pleistocene. Plagioclase picked from washed pelagic clay samples from the pelagic clay sequence is only moderately etched. It can be concluded especially considering the slow accumulation rate of pelagic clays, that the scarcity of plagioclase in the late Miocene reflects diminished volcanic activity in the area of provenance (probably the Lesser Antilles; no post-Eocene volcanoes are known, with minor exceptions, in the Greater Antilles or northern South America).

The scarcity of plagioclase in the Paleocene, Maestrichtian, and Campanian of Site 146 also suggests a diminution of volcanic activity during this interval. Plagioclase becomes more abundant in the early Santonian; however, some of this is associated with basaltic vulcanism within the basin 
$146 / 149$ 150

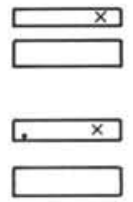

${ }^{\circ}$
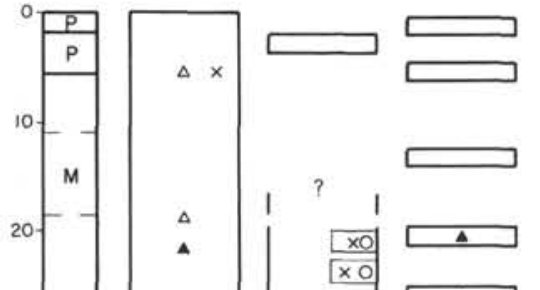

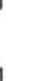
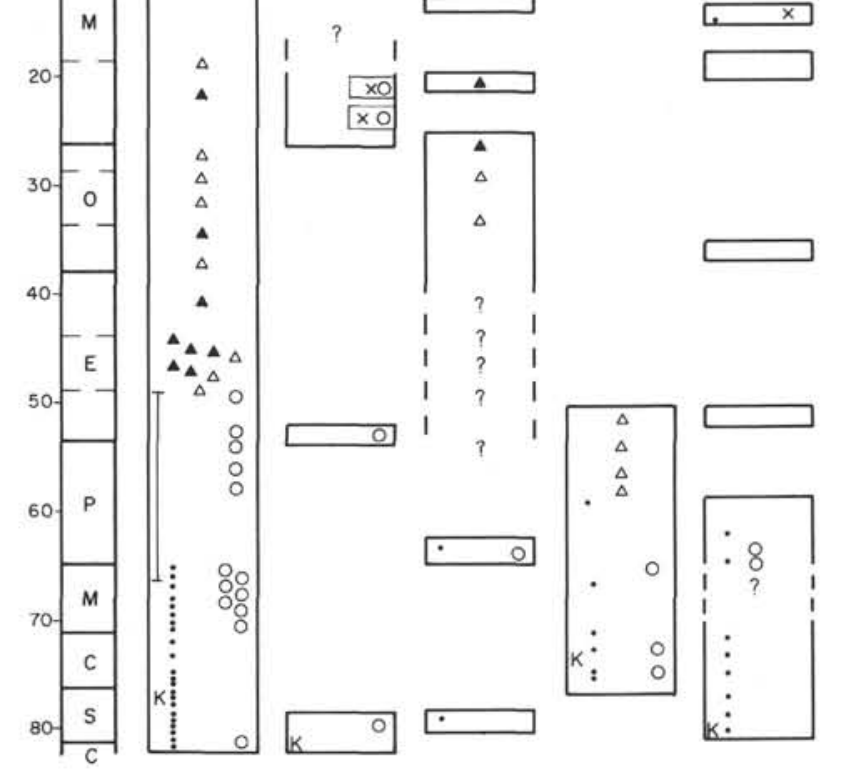

$$
\begin{array}{llll}
\Delta \text { pumice } & \times \text { phillpsite } & K \text { outhigenic K feldspar }
\end{array} \quad\left[\begin{array}{l}
\begin{array}{l}
\text { range of } \\
\text { cristobalite } \\
\text { in } 146
\end{array} \\
\begin{array}{l}
\Delta \text { other clear } \\
\text { glass }
\end{array}
\end{array}\right.
$$

Figure 4. Cores with occurrences of volcanic glass, zeolites, and other siliceous materials, in the central Caribbean. Plotted against time, as for Figure 2.

itself (Donnelly, et al., Basalts and dolerites from the central Caribbean, this volume).

In the Oligocene and Miocene portions of Sites 150, 151 , and 153 , there are insufficient samples to establish fluctuations in plagioclase distribution. However, the Paleocene, Maestrichtian, and Campanian portions of Sites 151,152 , and 153 have conspicuously more plagioclase than in Site 146. This observation, coupled with the abundance of hornblende and clinopyroxene at Sites 151 and 152 , suggests vulcanism in the northern Colombian Basin during that period.

At Site 148 and in the pelagic upper sequence of Site $154 \mathrm{~A}$, plagioclase is so nearly ubiquitous (Figures 6,7 ) that the mere occurrence of plagioclase is of little value in recording the waxing and waning of volcanic activity. In the analysis of Site 148 smear slides, a semiquantitative "volcanic index" was devised whereby values from 0 to 7 were assigned to smear slides according to the estimated abundance of plagioclase. The average of this index for each core is plotted in Figure 6 and seems to reflect, albeit poorly, the history of volcanic activity as gauged by other criteria (see below).

The occurrences of other volcanic minerals has been of less value in analyzing volcanic activity. However, the $\begin{array}{llll}146 / 149 & 150 & 151 & 152\end{array}$

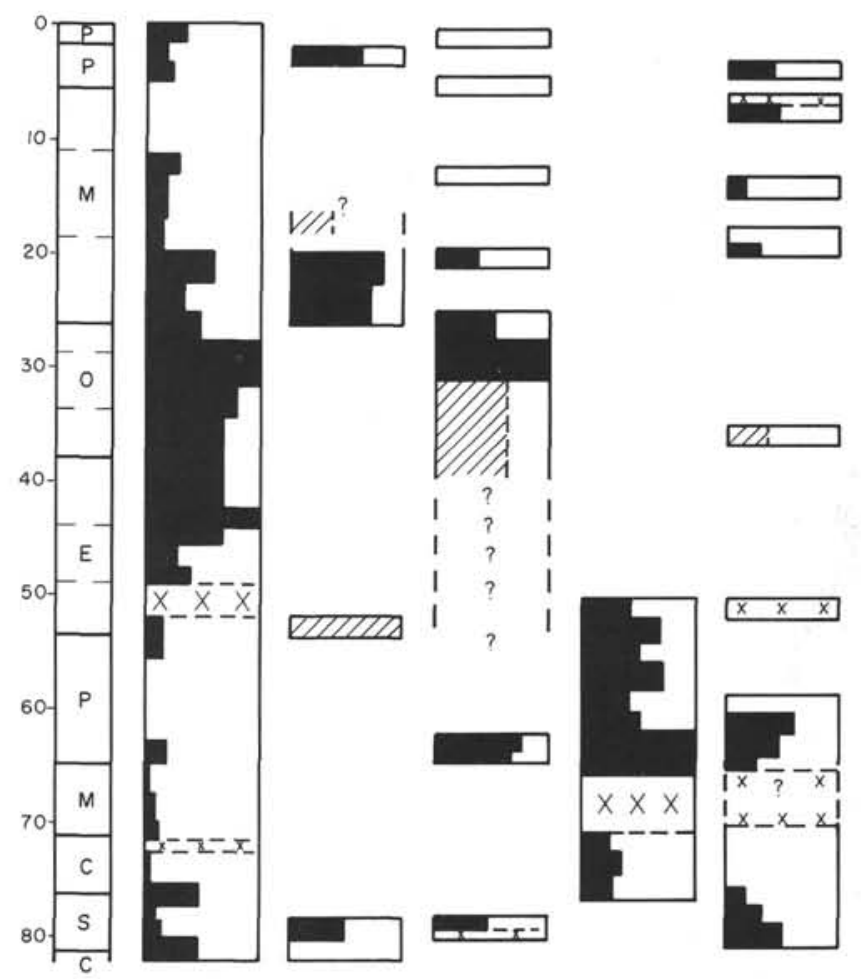

Figure 5. Histograms showing percentages of smear slides containing any plagioclase for the central Caribbean. Lined pattern indicates less than four smear slides examined. X-pattern indicates missing interval or no data. Plotted against time as explained in caption of Figure 2.

quartz-alkali feldspar-biotite-apatite-zircon assemblage (Figure 8) of the late Cretaceous of Sites 146, 151, and 152 appears to indicate volcanic activity which is decidedly more alkaline in character than the later plagioclaseproducing events of the Tertiary. Apatite, however, is widespread and associated with both typically calc-alkaline vulcanism (Sites 148, 154A, and 149) and the more sub-alkalic Cretaceous vulcanism. Hornblende and the pyroxenes are typically associated only with calc-alkalic vulcanism in this area. All three minerals, however, are considerably more scarce than plagioclase. Except for the two-pyroxene andesites of Pleistocene age in the Lesser Antilles and Central America, hornblende generally predominates among the mafic minerals of these rocks. Thus, its predominance in most of the Cretaceous and Tertiary samples from the central Caribbean is not remarkable.

Chemical criteria have been investigated as evidence for volcanic activity, but the results for major elements have not been useful (Donnelly, Mineralogy and chemistry of Noncalcareous sediments, this volume). Of the major element species, $\mathrm{Ca}, \mathrm{Si}$, and $\mathrm{P}$ are probably controlled by biological productivity and solution-recirculation effects. $\mathrm{Mg}, \mathrm{Na}$, and $\mathrm{K}$ are probably strongly controlled by 

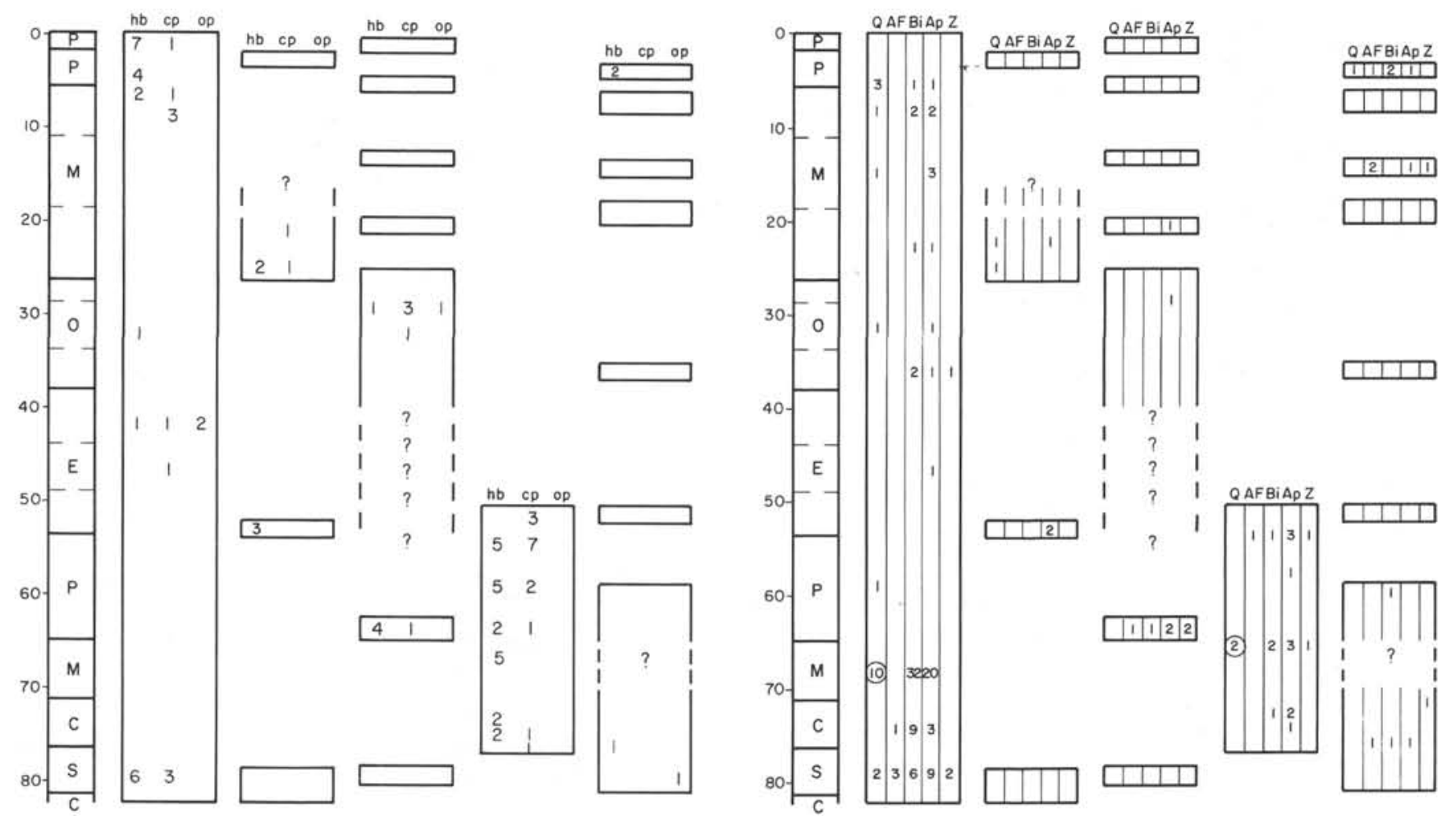

Figure 6. Histograms for Site 148 showing percentages of smear slides for each core containing plagioclase, red hornblende, green hornblende, clinopyroxene, orthopyroxene, and glass (lined pattern means fewer than four smear slides examined), and occurrences of other volcanic minerals. "Volcanic index" is a semiquantitative, relative measure of abundance of plagioclase for each core. "Equivalent major events" are the number of recognizable ash beds or dominant ash smear slides per core scaled to 9 meters recovery (assuming that the recovered portion is representative of the entire core). Nannofossil zones are shown at right.

interaction between solid phases and the interstitial water. The ratios of $\mathrm{Ti}, \mathrm{Al}, \mathrm{Mn}$, and $\mathrm{Fe}$ could prove useful, but a preliminary investigation has not been encouraging.

\section{HISTORY OF VOLCANIC ACTIVITY IN THE CENTRAL CARIBBEAN}

Mineralogical evidence (Figures 5, 8,9) suggests that the central Caribbean experienced a period of subalkalic volcanic activity in the late Santonian, Campanian, and Maestrichtian. Stratigraphic equivalents of this activity in surrounding land areas are well known: the Summerfield Formation of Jamaica (Coates, 1968; Roobol, in press), the Cariblanco Formation of Puerto Rico (Glover, 1971), the Knip Group of Curacao (Beets, 1971), and the Washikemba Formation of Bonaire (Beets and Lodder, 1967). All of these formations contain calc-alkalic minerals. For instance, the Hacienda Larga Tuff of the Cariblanco Formation has been described (Glover, 1971) as dominantly plagioclase

bearing, but with hornblende, biotite, minor sanidine and quartz. In addition, I have seen conspicuous apatite from one locality. The Washikemba ignimbrites, though poorly exposed and altered, contain plagioclase, quartz, biotite, and pyroxene phenocrysts (Beets and Lodder, 1967). I have seen abundant plagioclase, quartz, hornblende, and clinopyroxene grains in the Knip tuffite. A detailed petrographic desciption of the Summerfield Formation has not been published but my own brief field examination and Coates' (1968) description of "plagioclase, pyroxene, magnetite . . . and ... Some more acid volcanic rock fragments ..." suggests that this formation belongs to this subalkalic episode. Roobol (in press) describes pumiceous tuffs from the Summerfield Formation which contain feldspar, amphibole, biotite, quartz, and boulders of dacitic ash flow tuff. He states, "The Summerfield Formation marks an important period of dacite volcanism which ... is present entirely as pyroclastic material." The volcanic sandstones below Core 27, Site 148 (Plate 3, Figures 3 and 

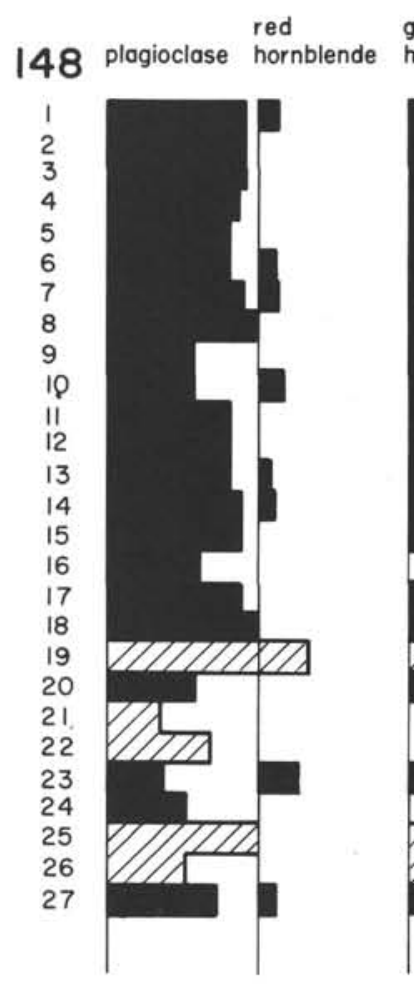

green

hornblende

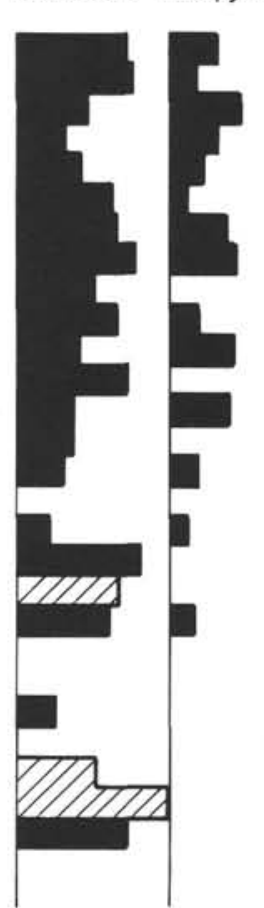

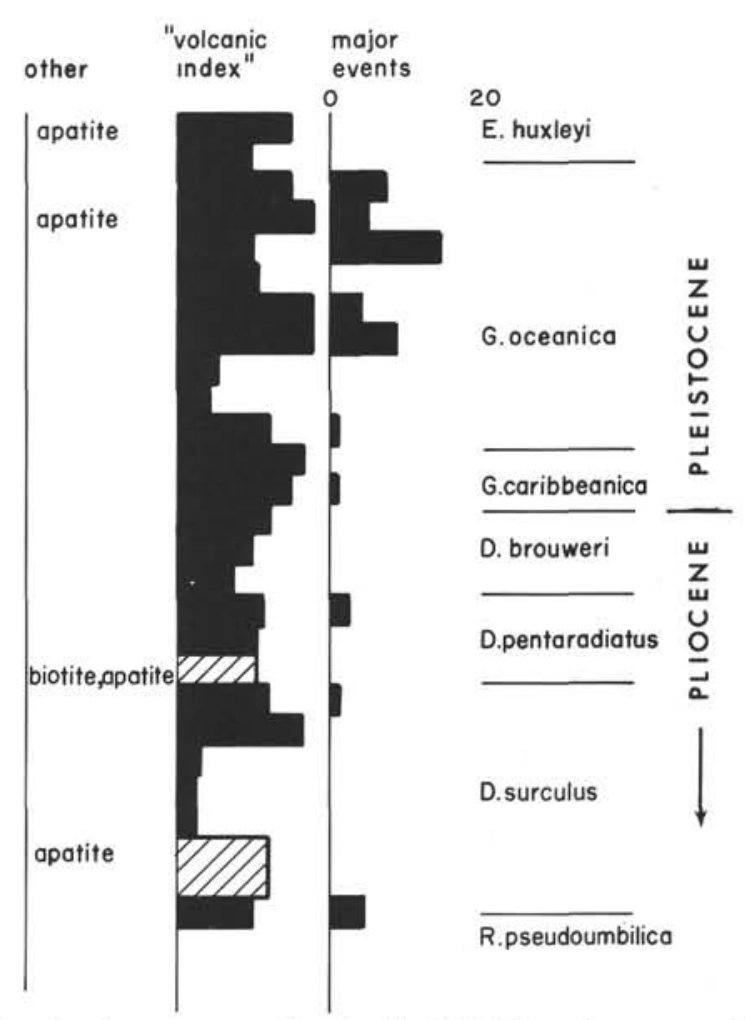

Figure 8. Number of occurrences (smear slides and picked samples) of volcanic quartz, volcanic alkali feldspar (some could be authigenic), biotite, apatite, and zircon, in the central Caribbean. Plotted against time, as explained in the caption of Figure 2 .

4), although containing a mixture of reworked fossils of Cretaceous through early Miocene ages, are very nearly identical to the Knip tuffites in mineralogy and lithology.

Continuation of vulcanism as more calc-alkalic activity through the Paleocene of the Colombian Basin is seen in the high content of volcanic debris at Site 152, which contrasts with the nearly nonvolcanic siliceous clay of Paleocene age at Site 146. Sites 151 and 153 show a relatively high percentage of plagioclase occurrences. The high rate of volcanic activity through the Cretaceous-Tertiary boundary of Site 152 corresponds with numerous occurrences of dredged basalt, one sample of which, from the Beata Ridge scarp, yielded a 65 my age (Fox, et al., 1970).

In mid-Eocene to early Miocene sediments of the Venezuelan Basin, numerous occurrences of pumice and glass (Figure 4), evidently of pumiceous origin, suggest, in conjunction with plagioclase abundance, that the eruption of pumiceous calc-alkaline materials occurred continually during this period. Volcanic centers of this age are essentially absent in the Greater Antilles and in northern South America, suggesting that the source was the Lesser Antilles, Central America, or both. The material was probably dominantly from the Lesser Antilles, however, because pumiceous material is scarce in Site 149 sediments younger than Oligocene. The major ignimbritic event of Central America is middle Miocene in age (McBirney and Williams, 1965; Williams and McBirney, 1969), a period of only limited volcanic detrital accumulation at Site 149.

The onset of this period, which corresponds to the change in lithology from relatively nonvolcanic, siliceous clays of the Paleocene and early Eocene, to more calcareous, volcanic oozes of mid-Eocene to early Miocene age, could be related to the major change in tectonic style which marked the termination of igneous and much structural activity in the Greater Antilles. Throughout the Greater Antilles, vulcanism and plutonism was widespread until the early Eocene and by late Eocene time it had ceased. Late Eocene and younger rocks of the Greater Antilles are nonvolcanic. In the Lesser Antilles, the earliest volcanic rocks are late Eocene. Thus, the cessation of Greater Antillean vulcanism may coincide with the onset of Lesser Antillean Tertiary volcanic activity. Unfortunately, the pre-Eocene of the Lesser Antilles, except for nonvolcanic Barbados, is unknown.

\section{PLIOCENE-PLEISTOCENE VOLCANIC ACTIVITY OF THE LESSER ANTILLES AND CENTRAL AMERICA}

The latest Tertiary history of volcanic activity in Central America is known to follow a phase of relative quiescence in late Miocene times (Weyl, 1961). In the Lesser Antilles, the volcanic cones are generally considered to have been initiated in the Pleistocene, or Pliocene, in some cases, on eroded basements of generally unknown, but presumably older ages (Robson and Tomblin, 1966). The eruption of the latest series of two-pyroxene andesites has been considered as beginning about Middle Pleistocene, largely from geomorphological inference.

The record of volcanic activity for the southern Lesser Antilles is seen especially clearly in a continuous core through Pliocene, Pleistocene, and Recent sediments at Site 


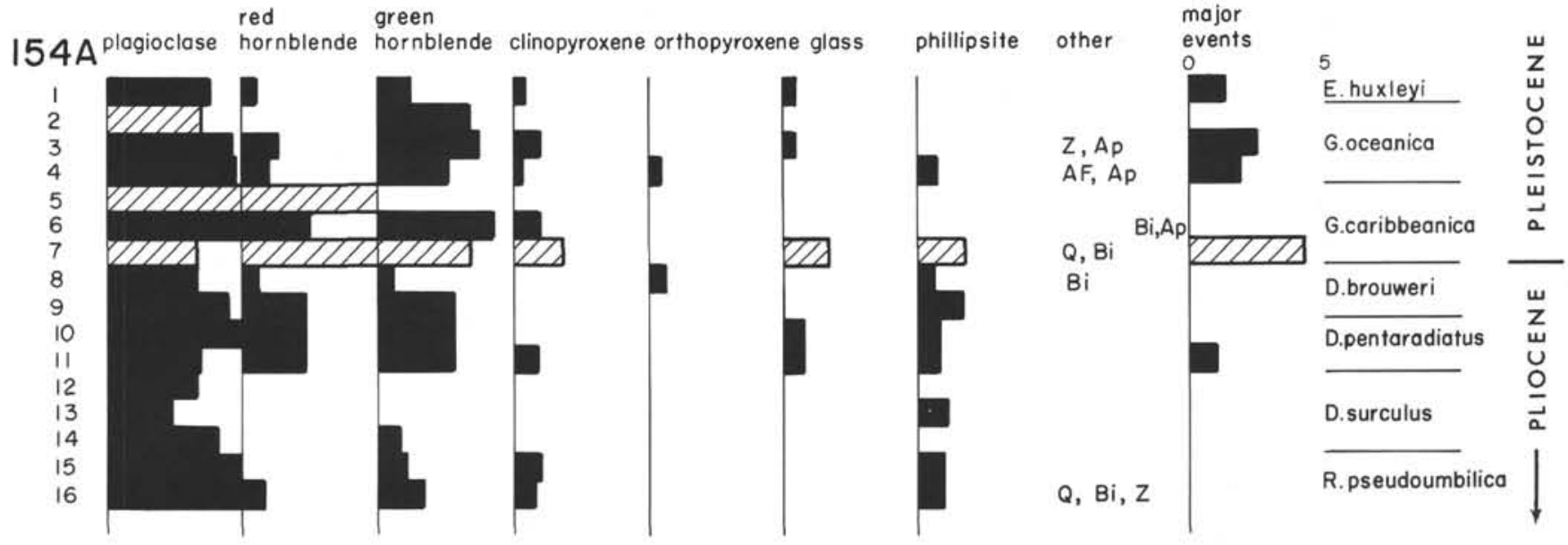

Figure 9. Number of occurrences (smear slides and picked samples) of hornblende, clinopyroxene, and orthopyroxene in the central Caribbean. Plotted against time, as explained in the caption of Figure 2.

148. The occurrences of volcanic minerals, of the "volcanic index" based on plagioclase abundance, and of "equivalent major events," (which is the number of major events per core based on 9.0 meters of recovery), indicate the diminution of volcanic activity in the mid-Pliocene, the increase in the late Pliocene and early Pleistocene, and the sudden appearance of highly explosive, two-pyroxene andesites (first appearances of glass and orthopyroxene) about the middle of the Pleistocene. Certain other minerals, such as red hornblende and apatite, appear to be quite unrelated to this later volcanic episode, but occur sporadically throughout.

\section{REFERENCES}

Beets, D. J., 1971. New data on the stratigraphy of Curacao, Netherlands Antilles. Trans. 5th Caribbean Geol. Conf. Queen's College Press. 85.

Beets, D. J. and Lodder, W., 1967. Indications for the presence of ignimbrites in the Cretaceous Washikemba
Formation of the Isle of Bonaire, Netherlands Antilles. Koninkl. Ned. Akad. Wetenschap. Phot. B., 70, 63.

Coates, A. G., 1968. The Geology of the Cretaceous Central Indies around Arthur's Seat, Clarendon, Jamaica. Trans. 4th Caribbean Geol. Conf., Trinidad, 306.

Fox, P. J., Ruddiman, W. F., Ryan, W. B. F. and Heezen, B. C., 1970. The geology of the Caribbean crust, I: Beata Ridge. Tectonophysics. 10, 495.

Glover, L., III, 1971. Geology of the Coamo area, Puerto Rico, and its relation to the volcanic arc-trench association. U.S. Geol. Surv. Profess. Paper. 636, 102 pp.

McBirney, A. R. and Williams, H., 1965. Volcanic history of Nicaragua. Univ. Calif. Publ..Geol. Sciences, 5565 pp.

Robson, G. R. and Tomblin, J. F., 1966. Catalogue of the active volcanoes of the world including solfatara fields. Part XX. West Indies. Internat. Assoc. of Volcanology, Rome. $56 \mathrm{pp}$.

Roobol, J. The volcanic geology of Jamaica. Trans. 6th Caribbean Geol. Conf. Margarita, July 1971 (in press).

Williams, H. and McBirney, A. R., 1969. Volcanic history of Honduras. Univ. Calif. Publ. Geol. Sciences, 85, $101 \mathrm{pp}$. 
T. W. DONNELLY

PLATE 1

Volcanic Feldspar Crystals

Figure 1 Fresh plagioclase coated with remnants of pumiceous glass. 149-31(CC). 206X. Late Eocene.

Figure 2 Plagioclase, from pelagic clay, showing solution rounding. 150-3(CC). 301X. Miocene.

Figure 3 Plagioclase from zeolitic (volcanic) clay. 150-4(CC). $250 X$. Miocene. 
PLATE 1
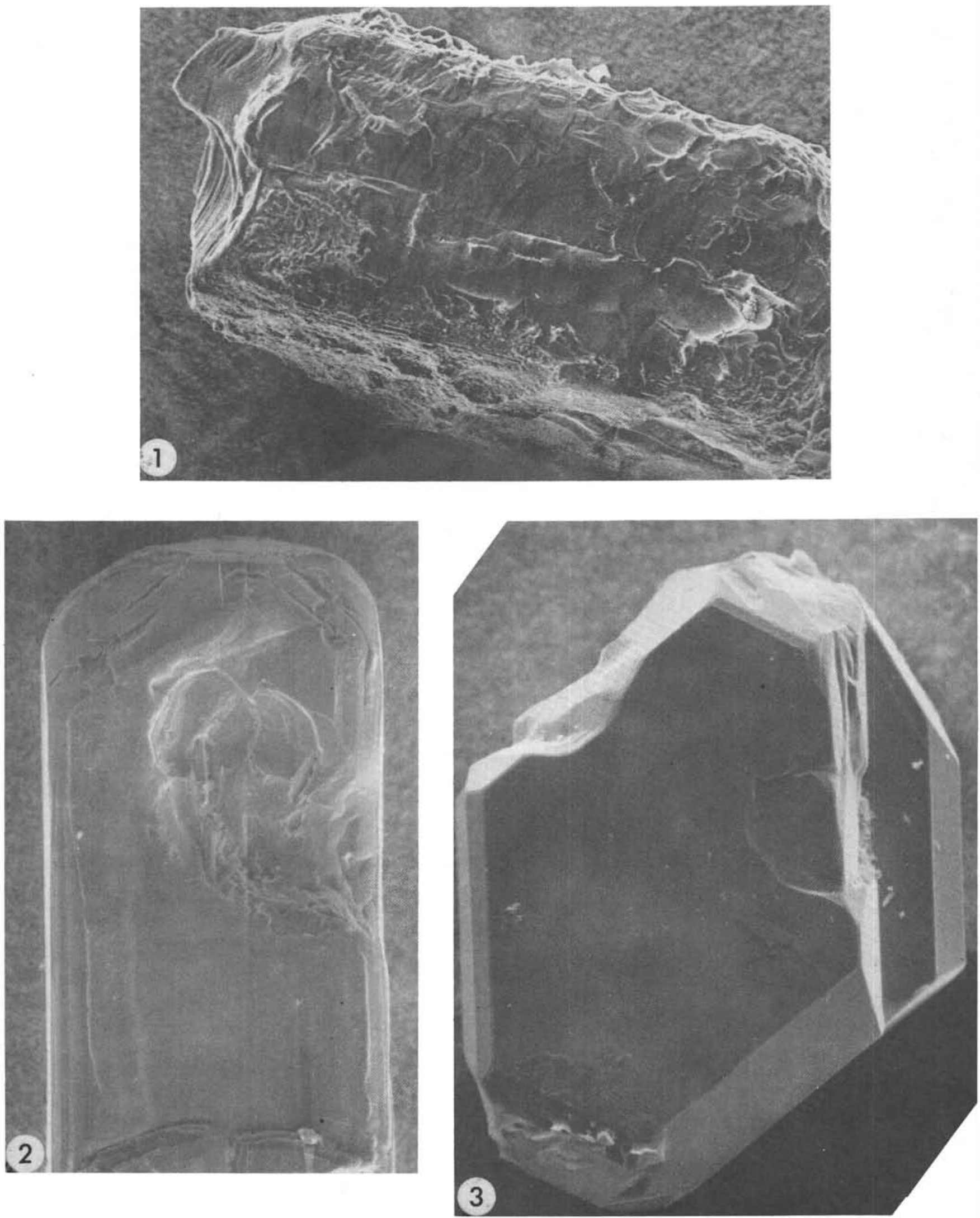


\section{PLATE 2 \\ Volcanic Crystals}

Figure 1 Magnetite showing octahedron modified by [100] and [110] faces. 150-4(CC). 151X. Miocene.

Figure 2 Clinopyroxene showing typical etch pattern. 150-3(CC). 151X. Miocene.

Figure 3 Bipyramidal quartz crystal. 153-2(CC). 470X. Miocene.

Figure $4 \quad$ Quartz crystal showing rounding caused by magmatic resorption. Darker patches may be vicinal faces. 146-16-4(78-81). 613X. Maestrichtian. 


\section{PLATE 2}
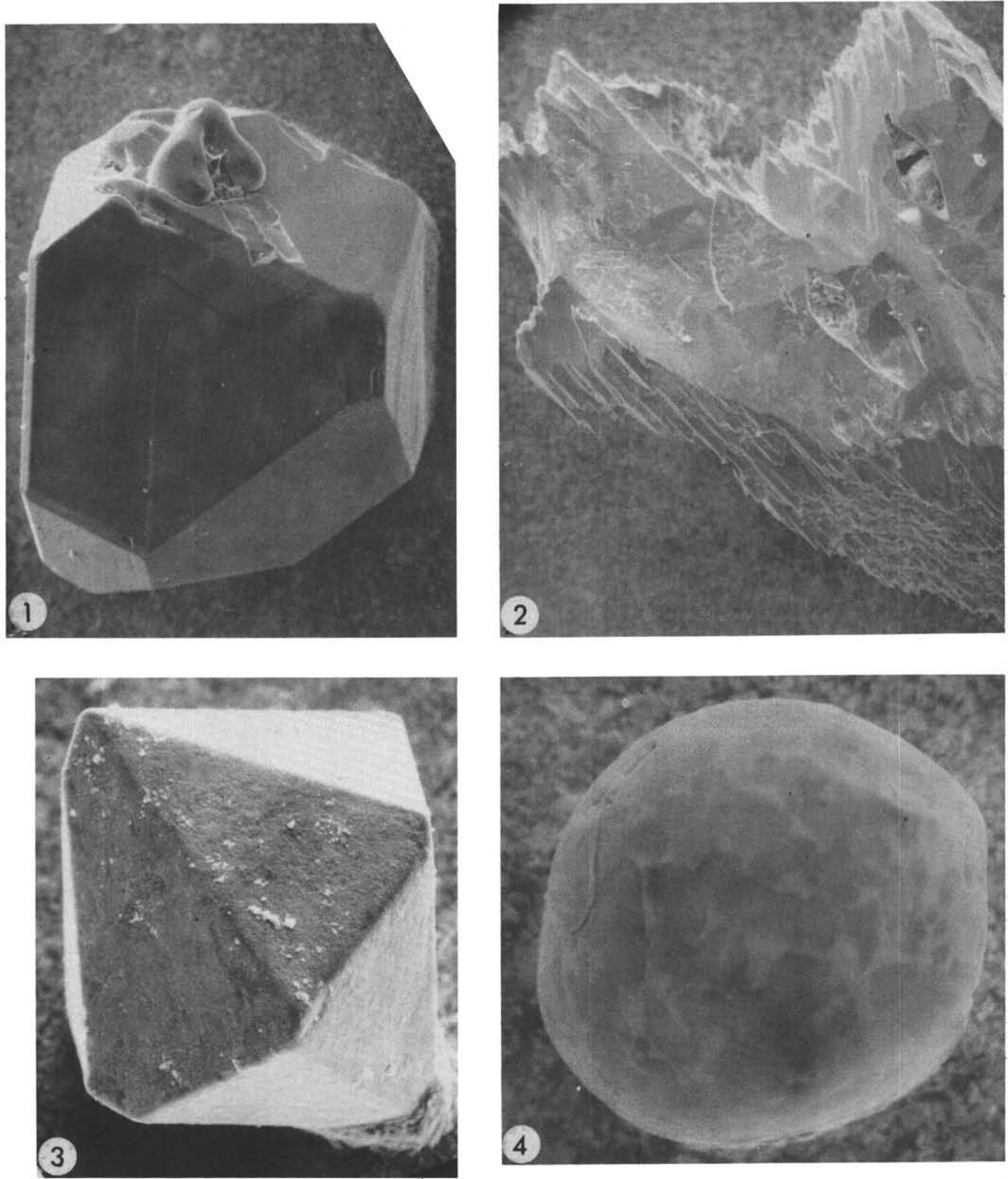


\section{PLATE 3}

Thin Sections of Volcanic Ashes and Sandstones (Bar is $1.0 \mathrm{~mm}$ long for each figure)

Figure 1 Basaltic ash, showing lower contact of bed, glauconitized palagonitic grains, and clear plagioclase crystal (left center). 146-39R-2(106-110). Santonian.

Figure 2 Basaltic ash, showing glauconitized palagonitic grains, porphyritic fragment (center) and augite grain (left center). 146-39R-2(94-108). Santonian.

Figures 3-4 Volcanic sandstone, showing clear quartz crystal, porphyritic andesitic fragments, glauconitic fragments, and ferruginous cement. 148-27(CC). Early Tertiary?. 


\section{PLATE 3}
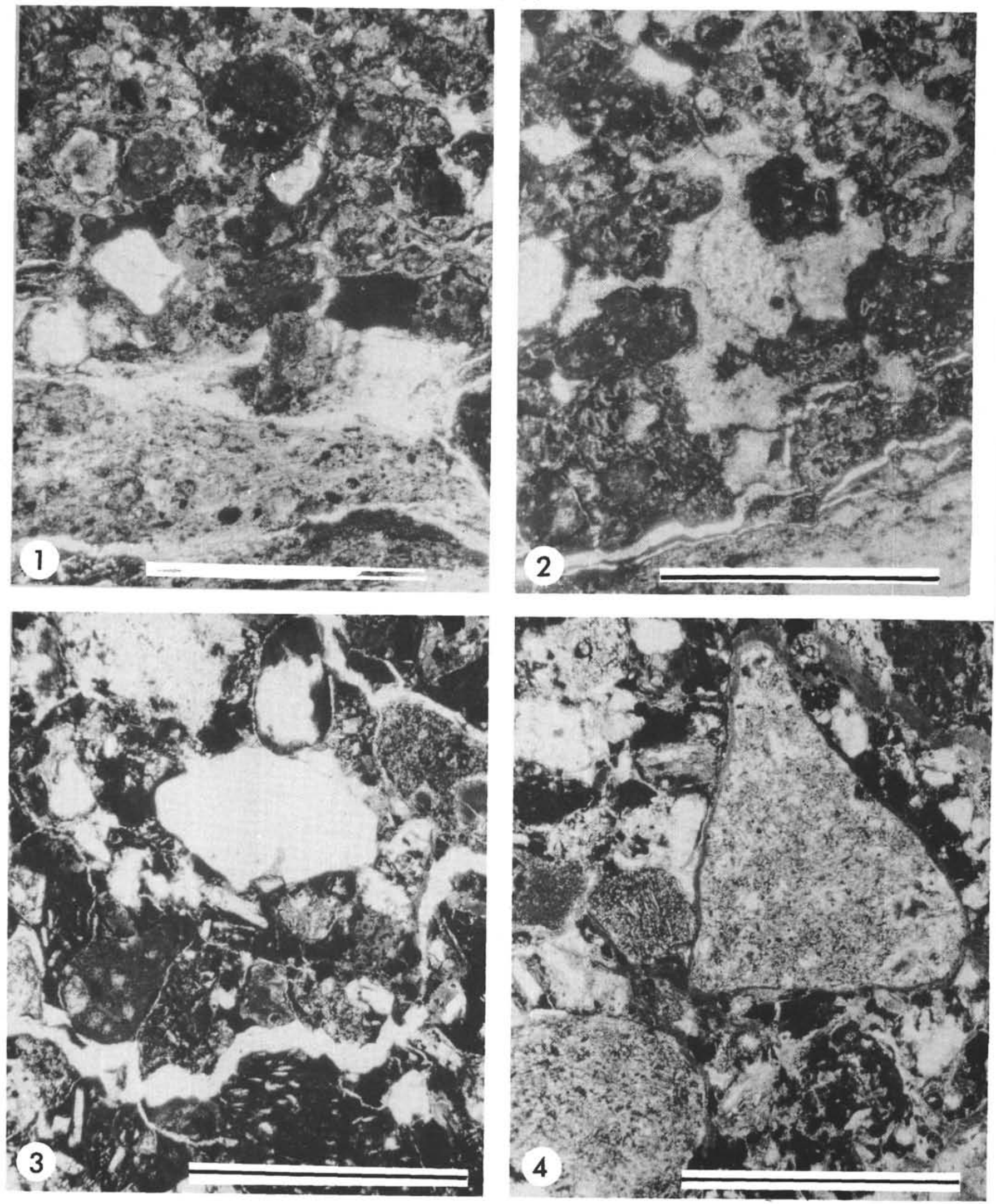


\section{PLATE 4}

Volcanic Ash

Figure 1 Glass shards (clear plates and darker tubular pumiceous shards), with radiolarians and sponge spicule. 152-2-2(115). Paleocene.

Figure 2 Glass shards (clear to nearly opaque), with radiolarians, sponge spicule, and foraminiferal debris. 152-2-1(139). Paleocene.

Figure 3 Crystal ash, with rounded quartz (lower left), apatite (upper right), abundant hornblende, alkali feldspar (clear, low relief), and foraminiferal debris. Plagioclase is nearly invisible. 152-10-1(147). Early Paleocene.

Figure $4 \quad$ Same slide as Figure 3, crossed nicols, showing rounded quartz, twinned plagioclase, alkali feldspar (no twinning), and foraminiferal debris. 


\section{PLATE 4}
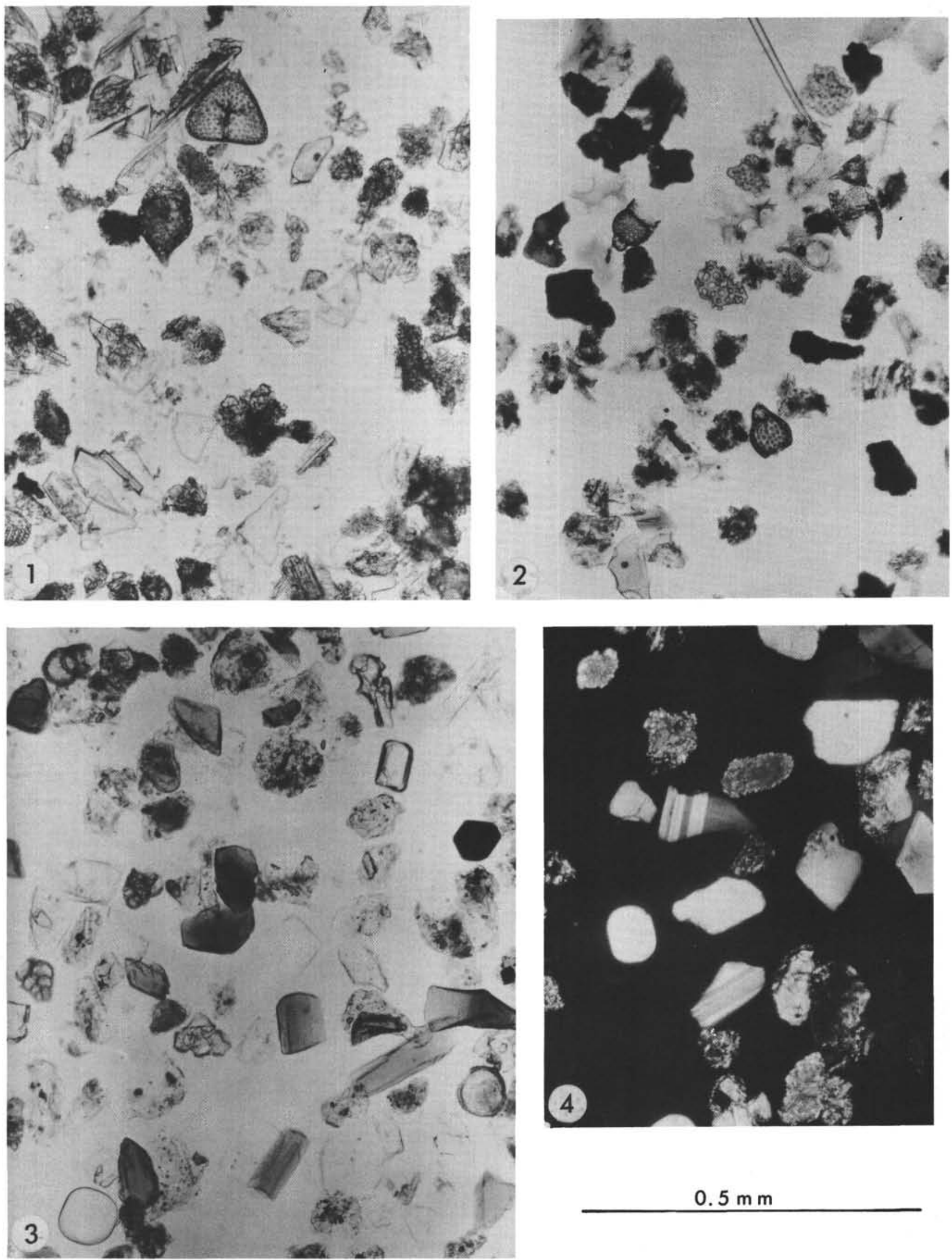


\section{PLATE 5}

Volcanic Crystals

Figure 1 Orthopyroxene (upper left) and clinopyroxene (lower right), both showing characteristically etched terminations, with phillipsite crystals, pyrite, chlorite, and fossil debris. 154-14-1(124). Bar is 100 microns. Late Miocene.

Figure 2 Clinopyroxene crystal, showing etching. 148-27(CC). Bar is 100 microns. Early Tertiary?

Figures 3-4 Zircon euhedra. 146-28-2(58). Bars are 100 microns long. Campanian.

Figure 5 Plagioclase crystal, flattened on [010], showing oscillatory zoning; crossed nicols. 149-11(CC). Early Pliocene. Bar is 100 microns long. 


\section{PLATE 5}
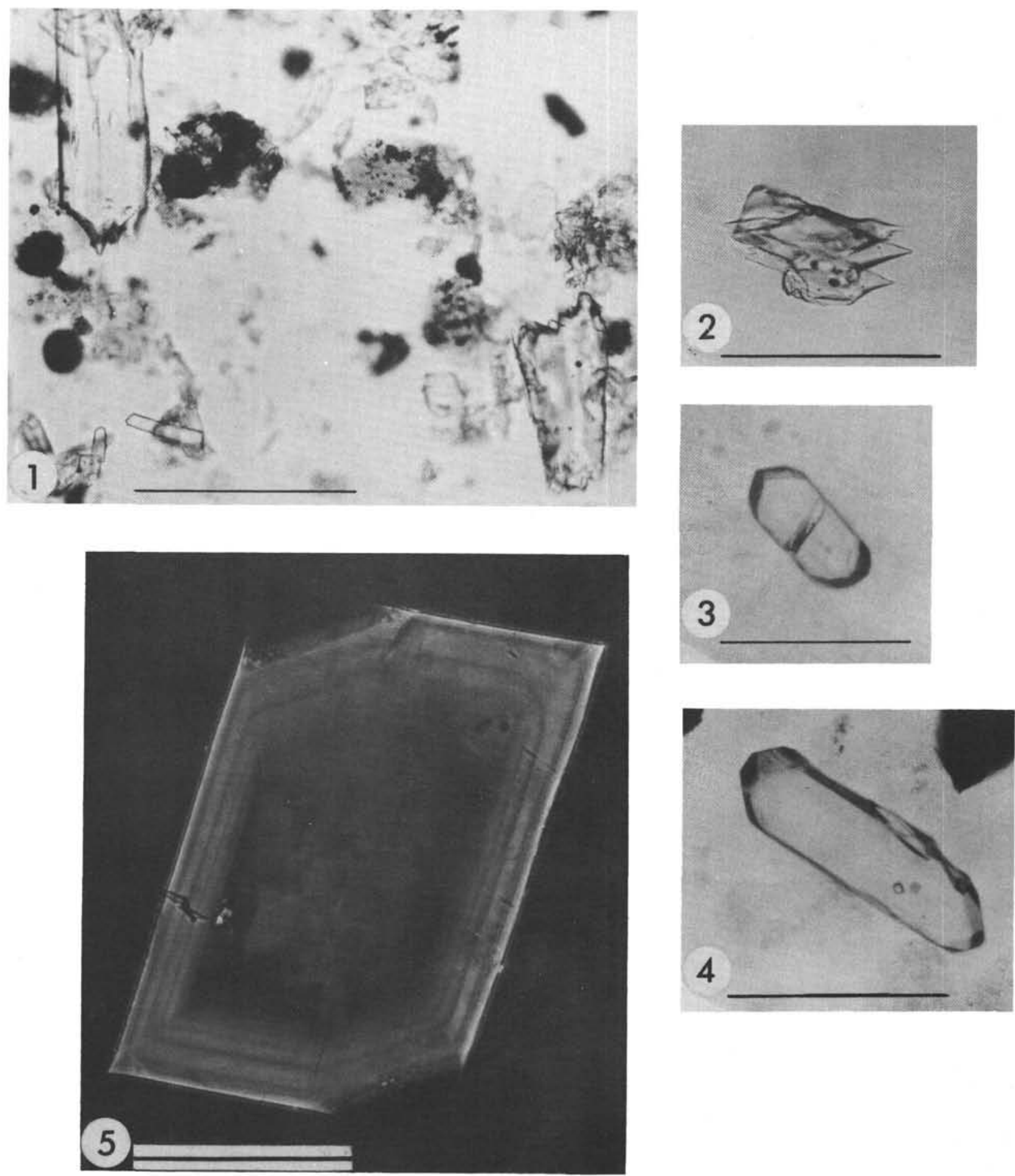
T. W. DONNELLY

\section{PLATE 6}

\section{Volcanic Apatite}

Figure 1 Apatite euhedron, with two-phase fluid inclusions (second phase not visible). 149-15(CC). Miocene.

Figure 2 Apatite euhedron, with fluid inclusions. 146-15-4(38-42). Maestrichtian.

Figure 3 Apatite euhedral basal plate. 146-16-1(123). Maestrichtian.

Figure 4 Apatite euhedron. 146-16-1(123). Maestrichtian. 


\section{PLATE 6}
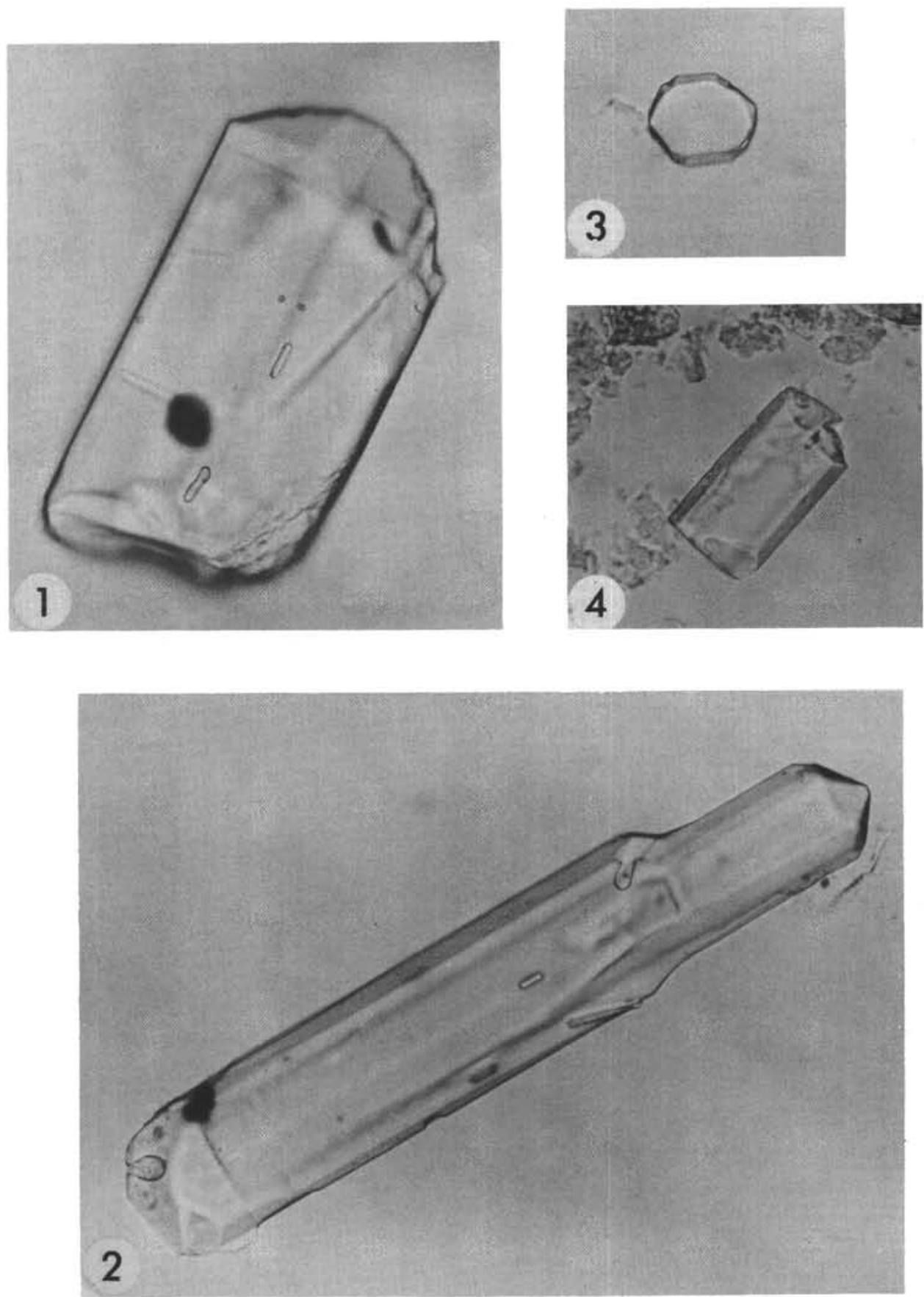

$100 \mu$ 